\title{
Different gene rearrangements of the genus Dardanus (Anomura: Diogenidae) and insights into the phylogeny of Paguroidea
}

Ying Zhang ${ }^{1}$, Lei Meng ${ }^{2}$, Liming Wei ${ }^{1}$, Xinting Lu ${ }^{1}$, Bingjian Liu ${ }^{1}$, Liqin Liu ${ }^{1}$, Zhenming Lü ${ }^{1}$, Yang Gao² \& Li Gong ${ }^{1 \bowtie}$

Complete mitochondrial genomes (mitogenomes) can provide useful information for phylogenetic relationships, gene rearrangement, and molecular evolution. In this study, the complete mitogenomes of two hermit crabs, Dardanus arrosor and Dardanus aspersus, were sequenced for the first time and compared with other published mitogenomes of Paguroidea. Each of the two mitogenomes contains an entire set of $\mathbf{3 7}$ genes and a putative control region, but they display different gene arrangements. The different arrangements of the two mitogenomes might be the result of transposition, reversal, and tandem duplication/random loss events from the ancestral pancrustacean pattern. Genome sequence similarity analysis reveals the gene rearrangement in 15 Paguroidea mitogenomes. After synteny analysis between the 15 Paguroidea mitogenomes, an obvious rearranged region is found in D. aspersus mitogenome. Across the 13 protein-coding genes (PCGs) tested, $\mathrm{COI}$ has the least and ND6 has the largest genetic distances among the 15 hermit crabs, indicating varied evolution rates of PCGs. In addition, the $\mathrm{dN} / \mathrm{dS}$ ratio analysis shows that all $\mathrm{PCGs}$ are evolving under purifying selection. The phylogenetic analyses based on both gene order and sequence data present the monophyly of three families (Paguridae, Coenobitidae, and Pylochelidae) and the paraphyly of the family Diogenidae. Meanwhile, the phylogenetic tree based on the nucleotide sequences of 13 PCGs shows that two Dardanus species formed a sister group with five Coenobitidae species. These findings help to better understand the gene rearrangement and phylogeny of Paguroidea, as well as provide new insights into the usefulness of mitochondrial gene order as a phylogenetic marker.

The metazoan mitochondrial genome (mitogenome) is typically a closed circular double-stranded DNA molecule. It is relatively small $(15-20 \mathrm{~kb})$ and contains 13 protein-coding genes (PCGs), 22 transfer RNA genes (tRNAs), two ribosomal RNA genes (12S and 16S), and an AT-rich region (also called control region, CR) ${ }^{1}$. Owing to some unique features like small genome size, conserved gene content, absence of introns, maternal inheritance, low level of recombination, and fast rate of evolution ${ }^{2,3}$, the mitogenome has been extensively used in population genetics, comparative genomics, and phylogenetic studies ${ }^{4-6}$. Besides, comparative analyses of the complete mitogenomes of closely related taxa can deepen the understanding of gene rearrangements and evolutionary relationships $\mathrm{s}^{7,8}$.

Generally, the gene order in most vertebrate mitogenomes is considered conserved. However, extensive mitochondrial gene rearrangements have been observed in invertebrate mitogenomes, such as in cephalopods ${ }^{9}$, bivalves ${ }^{10}$, insects ${ }^{11}$, and crabs $^{12,13}$. The gene rearrangement within a lineage has been supposed to be phylogenetically informative; therefore, comparative analysis of mitochondrial gene order has been proved to be a valuable phylogenetic tool. For example, Yuan et al. ${ }^{14}$ compared the mitochondrial gene arrangements of six heterodont bivalves and concluded that Sanguinolaria (Psammobiidae) is not monophyletic. By gene order comparisons of echinoderms, Smith et al..$^{15}$ provided evidence that the sea cucumbers should group with sea urchins and sea stars with brittle stars. Besides, Morrison et al. ${ }^{16}$ reconstructed a phylogeny for decapod taxa based on gene rearrangements and DNA sequences. Their findings supported five independent origins of the crab-like form

\footnotetext{
${ }^{1}$ National Engineering Laboratory of Marine Germplasm Resources Exploration and Utilization, National Engineering Research Center for Facilitated Marine Aquaculture, Marine Science and Technology College, Zhejiang Ocean University, Zhoushan 316022, China. ${ }^{2}$ School of Fishery, Zhejiang Ocean University, Zhoushan 316022, China. ${ }^{\boxplus}$ email: gongli1027@163.com
} 
and confirmed the utility of mitochondrial gene rearrangements in phylogenetic reconstruction. So far, three main types of gene rearrangement events have been observed in the mitogenomes of animals, including translocation, shuffling, and inversion ${ }^{17-20}$. Correspondingly, four mechanisms have been proposed to account for mitogenomic rearrangements, including tandem duplication/random loss (TDRL) model ${ }^{21}$, tRNA mis-priming model $^{22}$, intramitochondrial recombination model ${ }^{23}$, and tandem duplication/non-random loss model ${ }^{24}$.

The infraorder Anomura consists of approximately 2450 extant species ${ }^{25}$ with a broad range of ecological specializations and with various lineages having successfully adapted to freshwater, terrestrial, and diverse marine environments ${ }^{6}$. The latest classification scheme divides Anomura into Aegloidea, Chirostyloidea, Galatheoidea, Hippoidea, Lithodoidea, Lomisoidea, and Paguroidea. Hermit crabs (the superfamily Paguroidea Latreille, 1802) consist of Coenobitidae, Diogenidae, Paguridae, Parapaguridae, Pylochelidae and Pylojacquesidae, with more than 1100 species inhabiting diverse biotopes from intertidal to deep seas ${ }^{26}$. They represent an intermediate group of crustaceans from Macrura to Brachyura, which occupy an important position in crustacean evolution ${ }^{27}$. However, their evolutionary relationships at many taxonomic levels are still waiting for researchers to resolve $\mathrm{e}^{28-30}$. Diogenidae Ortmann, 1892 is the second largest family of the superfamily Paguroidea. According to WoRMS (http://www.marinespecies.org/), the family Diogenidae has 22 genera and 482 species in total. Among them, the genus Dardanus Paulson, 1875 is one of the most diverse genera within Diogenidae. Previous studies of this genus mainly focused on morphology $y^{31,32}$, with almost no attention given to molecular phylogeny. To date, the phylogenetic location of the genus Dardanus has not been well resolved.

Accordingly, in the present study, we newly sequenced and annotated the complete mitogenomes of two hermit crabs, D. arrosor and D. aspersus. These are the first published mitogenomes of the genus Dardanus. Combined with 13 available Paguroidea mitogenomes, we performed a comparative mitogenomics analysis, in order to: (a) investigate the characteristics of Paguroidea mitogenomes; (b) estimate the phylogenetic information of mitochondrial gene rearrangements; (c) reconstruct the phylogeny of Paguroidea that could lay a foundation for further evolutionary studies.

\section{Materials and methods}

Sampling, DNA extraction, mitogenome sequencing, and assembly. Specimens of D. arrosor and D. aspersus were collected from Zhoushan Province, China ( $\left.29^{\circ} 45^{\prime} 32^{\prime \prime} \mathrm{N}, 121^{\circ} 45^{\prime} 30^{\prime \prime} \mathrm{E}\right)$. Specimens were immediately preserved in 95\% ethanol until DNA extraction. The SQ Tissue DNA Kit (OMEGA) was used to extract the total genomic DNA from muscle tissue following the manufacturer's instructions. The genomic DNA was sent to Shanghai Origingene Biopharm Technology Co., Ltd. for library preparation and high-throughput sequencing. The libraries were constructed by using the VAHTS Universal Plus DNA Library Prep Kit, with an insert size of $150 \mathrm{bp}$. Paired-end sequencing with a read length of $150 \mathrm{bp}$ was performed on an Illumina Hiseq 6000 platform. Adapters and low-quality bases were removed using cutadapt v1.16 $6^{33}$ with the following parameters: -q 20 -m 20. Trimmed reads shorter than 50 bp were discarded. Quality control of raw and trimmed reads was performed using FastQC v0.11.5 (http://www.bioinformatics.babraham.ac.uk/projects/fastqc/). The filtered clean data were assembled and mapped to complete mitogenome sequence using NOVOPlasty v2.7.2 ${ }^{34}$.

Mitogenome annotation and sequence analysis. The newly assembled mitogenomes of $D$. arrosor and D. aspersus were annotated using the software of Sequin (version 15.10, http://www.ncbi.nlm.nih.gov/ Sequin/). The boundaries of protein-coding and ribosomal RNA genes were performed using NCBI-BLAST (http://blast.ncbi.nlm.nih.gov). Transfer RNA genes were manually plotted, according to the secondary structure predicted by the MITOS Web Server ${ }^{35}$ and tRNAscan-SE $1.21^{36}$. The control region was determined by the locations of adjacent genes. Finally, circular mitogenome maps of $D$. arrosor and $D$. aspersus were drawn with the BLAST Ring Image Generator (BRIG) v0.95

The base composition and relative synonymous codon usage (RSCU) were obtained using MEGA $\mathrm{X}^{38}$. The strand asymmetry was calculated using the following formulas: AT-skew $=(A-T) /(A+T)$; GC-skew $=(G-C) /$ $(\mathrm{G}+\mathrm{C})^{39}$. Furthermore, we chose the complete mitogenome of Pagurus filholi as the reference genome for comparative genomic analysis. Genome sequence similarity among the 15 Paguroidea species was carried out using the BRIG tool. Synteny analysis between the genomes was performed using Mauve v2.4.0 ${ }^{40}$. To estimate the evolutionary-selection constraints on 13 PCGs in the superfamily Paguroidea, the nonsynonymous (dN) and synonymous $(\mathrm{dS})$ substitution rates were calculated using Mega X. The genetic distances of 13 PCGs were also estimated using Mega X based on the Kimura 2-parameter (K2P) substitution model.

Mitochondrial gene order comparisons and phylogeny. $\mathrm{CREx}^{41}$ was used to compare the mitochondrial gene order and infer the gene rearrangement scenarios based on common intervals. CREx considers four types of rearrangement events: reversals (R), transpositions (T), reverse transpositions (RT), and tandem-duplication-random-losses (TDRL). MLGO web server ${ }^{42}$ was used to infer a phylogeny from gene order data.

Phylogenetic analysis. Phylogeny of the Paguroidea was inferred based on 13 available complete mitogenomes expanded with the two newly determined ones (Table 1). The species Helicana wuana and H. latimera from Grapsoidea were used as outgroups. Fasta files with the nucleotide sequences for all 13 PCGs were extracted from the GenBank files using PhyloSuite ${ }^{43}$. The MAFFT program ${ }^{44}$ integrated into PhyloSuite was executed to align multiple sequences in normal-alignment mode, and ambiguously aligned regions were identified and moved by Gblocks ${ }^{45}$. Subsequently, the sequences were concatenated into a single alignment and converted into input files (Phylip and Nexus format) for phylogenetic analyses. Phylogenetic trees were built under maximum likelihood (ML) and Bayesian inference (BI) methods. The ML analysis was conducted using IQ-TREE ${ }^{46}$, under an ML + rapid bootstrap (BS) algorithm with 1000 replicates. The BI analysis was conducted in MrBayes 


\begin{tabular}{|l|l|l|l|l|l|}
\hline Species & Family & Superfamily & Length (bp) & Accession No & References \\
\hline Pagurus filholi & Paguridae & Paguroidea & 15,674 & LC222528 & 48 \\
\hline Pagurus japonicus & Paguridae & Paguroidea & 16,401 & LC222532 & 48 \\
\hline Pagurus gracilipes & Paguridae & Paguroidea & 16,051 & LC222534 & 48 \\
\hline Pagurus maculosus & Paguridae & Paguroidea & 15,420 & LC222524 & 48 \\
\hline Pagurus nigrofascia & Paguridae & Paguroidea & 15,423 & LC222531 & 48 \\
\hline Pagurus longicarpus & Paguridae & Paguroidea & 15,630 & NC_003058 & 49 \\
\hline Coenobita rugosus & Coenobitidae & Paguroidea & 16,427 & KY352235 & 6 \\
\hline Coenobita variabilis & Coenobitidae & Paguroidea & 16,421 & KY352236 & 6 \\
\hline Coenobita perlatus & Coenobitidae & Paguroidea & 16,447 & KY352234 & 6 \\
\hline Coenobita brevimanus & Coenobitidae & Paguroidea & 16,393 & NC_050386 & 50 \\
\hline Birgus latro & Coenobitidae & Paguroidea & 16,411 & NC_045091 & 51 \\
\hline Dardanus arrosor & Diogenidae & Paguroidea & 16,592 & MW147148 & This study \\
\hline Dardanus aspersus & Diogenidae & Paguroidea & 16,916 & MW715812 & This study \\
\hline Clibanarius infraspinatus & Diogenidae & Paguroidea & 16,504 & NC_025776 & 52 \\
\hline Pylocheles mortensenii & Pylochelidae & Paguroidea & 15,093 & KY352242 & 6 \\
\hline Helice wuana & Varunidae & Grapsoidea & 16,359 & NC_034995 & Outgroup \\
\hline Helice latimera & Varunidae & Grapsoidea & 16,246 & NC_033865 & Outgroup \\
\hline
\end{tabular}

Table 1. Basic information of 15 Paguroidea species and two outgroups used in this paper.

3.2.6 $6^{47}$ with $3 \times 10^{6}$ metropolis-coupled Markov Chain Monte Carlo (MCMCMC) generations, sampling every 1000 generations, and the first $25 \%$ of the generations were discarded as burn-in. To guarantee the stationarity had been reached, the average standard deviation of split frequencies was set below 0.01 .

\section{Results}

General features of $D$. arrosor and $D$. aspersus mitogenomes. The complete mitogenomes of $D$. arrosor and $D$. aspersus are 16,592 bp and 16,916 bp in length, respectively (GenBank accessions MW147148 and MW715812) (Figs. S1, S2, Tables 1, 2). Each mitogenome contains a typical set of 37 genes (13 PCGs, 22 tRNAs, and two rRNAs) and a putative CR. Within these genes, eight PCGs (COI, COII, ND2, ATP8, ATP6, COIII, ND6, and Cyt b) and 11 tRNAs (tRNA-Leu ${ }^{\mathrm{TAG}}$, Lys, Met, Ile, Asp, Arg, Asn, Glu, Thr, Ser ${ }^{\mathrm{TGA}}$, and Tyr) are encoded by the heavy (H-) strand, while five PCGs (ND5, ND4, ND4L, ND1, and ND3), 11 tRNAs (tRNA-Phe, His, Pro, Val, Ser ${ }^{\mathrm{TCT}}$, Ala, Gly, Leu ${ }^{\mathrm{TAA}}, \operatorname{Tr} p, \mathrm{Gln}$, and Cys), and two rRNAs (16S and $12 S$ rRNA) are encoded by the light (L-) strand. But the gene order of the two mitogenomes is different.

There are 214 intergenic nucleotides (IGNs) dispersed in 22 locations for D. arrosor, 596 IGNs in 22 locations for D. aspersus. The longest IGN is $64 \mathrm{bp}$ (between $t R N A-H i$ and ND4) and 176 bp (between ND4L and tRNA-Pro) for D. arrosor and D. aspersus, respectively (Tables 2, 3). Meanwhile, 27 overlapping nucleotides are located in seven pairs of neighboring genes for both mitogenomes. These overlapping nucleotides vary in length from 1 to $7 \mathrm{bp}$, and the longest overlap is located between ATP8 and ATP6 as well as ND4 and ND4L (Tables 2, 3 ). The base composition of $D$. arrosor is $\mathrm{A}=33.3 \%, \mathrm{~T}=34.6 \%, \mathrm{C}=15.7 \%, \mathrm{G}=16.4 \%$ and that of $D$. aspersus is $\mathrm{A}=33.4 \%, \mathrm{~T}=32.6 \%, \mathrm{C}=15.7 \%, \mathrm{G}=18.3 \%$. The $\mathrm{AT}$ content is $67.9 \%$ in $D$. arrosor and $66.0 \%$ in $D$. aspersus, thus exhibiting a strong AT bias (Tables S1, S2).

Except for ND5 (uses GTG as the start codon) and ND3 (uses TTG as the start codon) in D. aspersus mitogenome (Tables 2,3), the remaining PCGs initiate with typical ATN codons. As for the stop codon, the majority of PCGs stop with TAA or TAG except for ND5 (uses a single T as the stop codon) and ND6 (uses GAC as the stop codon) in the two mitogenomes (Tables 2, 3). The GC-skew values of five PCGs (ND5, ND4, ND4L, ND1, and ND3) are positive, indicating they are encoded by the L-strand, whereas the remaining eight exhibit negative values, indicating they are encoded by the H-strand (Tables S1, S2).

Twenty-two tRNAs of $D$. arrosor and $D$. aspersus mitogenomes are scattered throughout the entire mitogenome (Tables 2, 3). The total length of 22 tRNAs is $1455 \mathrm{bp}$ in D. arrosor and $1460 \mathrm{bp}$ in D. aspersus (Tables S1, $\mathrm{S} 2$ ). All of the tRNAs can be folded into typical cloverleaf secondary structures except for the $t$ RNA-Ser (TCT) in the two mitogenomes (Figs. S3, S4). The lack of DHU arm in $t R N A-S e r$ (TCT) is thought to be a common phenomenon in metazoan mitogenomes ${ }^{12,53}$. The $16 S$ rRNA and $12 S$ rRNA genes of D. arrosor and D. aspersus are located between ND1 and $t R N A-V a l$ and between $t R N A-V a l$ and CR, respectively. The AT content of the two rRNAs is $73.3 \%$ in D. arrosor, which is higher than that of D. aspersus $(70.1 \%)$ (Tables S1, S2).

Codon usage bias in Paguroidea mitogenomes. Codon usage bias is a phenomenon in which specific codons are used more frequently than other synonymous codons by certain organisms during the translation of genes to proteins. In this study, the relative synonymous codon usage (RSCU) of 15 hermit crabs is roughly identical. Except for Pagurus longicarpus and Pylocheles mortensenii, which miss codons, the other 13 species have all 62 available codons. The lost codons usually belong to GC-rich codon-families (Fig. S5, Table S3). The RSCU values for the codons NNU and NNA are usually greater than one, suggesting a strong AT bias in the third 


\begin{tabular}{|c|c|c|c|c|c|c|c|c|}
\hline \multirow[b]{2}{*}{ Gene } & \multicolumn{2}{|c|}{ Position } & \multirow[b]{2}{*}{ Length (bp) } & \multirow[b]{2}{*}{ Amino acid } & \multirow[b]{2}{*}{ Start/stop codon } & \multirow[b]{2}{*}{ Anticodon } & \multirow[b]{2}{*}{ Intergenic region } & \multirow[b]{2}{*}{ Strand } \\
\hline & From & To & & & & & & \\
\hline $\mathrm{COI}$ & 1 & 1539 & 1539 & 512 & ATG/TAA & & -5 & $\mathrm{H}$ \\
\hline $\operatorname{Leu}\left(L_{1}\right)$ & 1535 & 1597 & 63 & & & TAG & 4 & $\mathrm{H}$ \\
\hline COII & 1602 & 2294 & 693 & 230 & ATG/TAG & & 6 & $\mathrm{H}$ \\
\hline Lys $(K)$ & 2301 & 2367 & 67 & & & TTT & 8 & $\mathrm{H}$ \\
\hline $\operatorname{Met}(M)$ & 2376 & 2443 & 68 & & & CAT & 7 & $\mathrm{H}$ \\
\hline Ile $(I)$ & 2451 & 2514 & 64 & & & GAT & 52 & $\mathrm{H}$ \\
\hline ND2 & 2567 & 3568 & 1002 & 333 & ATT/TAG & & 4 & $\mathrm{H}$ \\
\hline $\operatorname{Asp}(D)$ & 3573 & 3637 & 65 & & & GTC & 0 & $\mathrm{H}$ \\
\hline ATP8 & 3638 & 3796 & 159 & 52 & ATT/TAG & & -7 & $\mathrm{H}$ \\
\hline ATP6 & 3790 & 4464 & 675 & 224 & ATG/TAA & & -1 & $\mathrm{H}$ \\
\hline COIII & 4464 & 5255 & 792 & 263 & ATG/TAA & & 11 & $\mathrm{H}$ \\
\hline $\operatorname{Arg}(R)$ & 5267 & 5333 & 67 & & & TCG & -1 & $\mathrm{H}$ \\
\hline $\operatorname{Asn}(N)$ & 5333 & 5397 & 65 & & & GTT & 3 & $\mathrm{H}$ \\
\hline Glu $(E)$ & 5401 & 5466 & 66 & & & TTC & 1 & $\mathrm{H}$ \\
\hline Phe $(F)$ & 5468 & 5532 & 65 & & & GAA & 8 & $\mathrm{~L}$ \\
\hline ND5 & 5541 & 7260 & 1720 & 573 & ATG/T & & 0 & $\mathrm{~L}$ \\
\hline His $(H)$ & 7261 & 7325 & 65 & & & GTG & 64 & $\mathrm{~L}$ \\
\hline ND4 & 7390 & 8820 & 1431 & 476 & ATG/TAA & & -7 & $\mathrm{~L}$ \\
\hline$N D 4 L$ & 8814 & 9116 & 303 & 100 & ATG/TAA & & 2 & $\mathrm{~L}$ \\
\hline $\operatorname{Thr}(T)$ & 9119 & 9185 & 67 & & & TGT & 12 & $\mathrm{H}$ \\
\hline ND6 & 9198 & 9716 & 519 & 172 & ATG/GAC & & -5 & $\mathrm{H}$ \\
\hline$C y t b$ & 9712 & 10,848 & 1137 & 378 & ATG/TAG & & -1 & $\mathrm{H}$ \\
\hline $\operatorname{Ser}\left(S_{2}\right)$ & 10,848 & 10,913 & 66 & & & TGA & 2 & $\mathrm{H}$ \\
\hline Pro $(P)$ & 10,916 & 10,982 & 67 & & & TGG & 3 & $\mathrm{~L}$ \\
\hline ND1 & 10,986 & 11,915 & 930 & 309 & ATT/TAG & & 0 & $\mathrm{~L}$ \\
\hline $16 S$ & 11,916 & 13,322 & 1407 & & & & 0 & $\mathrm{~L}$ \\
\hline $\operatorname{Val}(V)$ & 13,323 & 13,391 & 69 & & & TAC & 1 & $\mathrm{~L}$ \\
\hline $12 S$ & 13,393 & 14,190 & 798 & & & & 0 & $\mathrm{~L}$ \\
\hline $\mathrm{CR}$ & 14,191 & 15,686 & 1496 & & & & 0 & $\mathrm{H}$ \\
\hline $\operatorname{Ser}\left(S_{1}\right)$ & 15,687 & 15,753 & 67 & & & TCT & 0 & $\mathrm{~L}$ \\
\hline Ala $(A)$ & 15,754 & 15,815 & 62 & & & TGC & 5 & L \\
\hline ND3 & 15,821 & 16,168 & 348 & 115 & ATT/TAG & & 3 & $\mathrm{~L}$ \\
\hline Gly $(G)$ & 16,172 & 16,237 & 66 & & & TTC & 1 & $\mathrm{~L}$ \\
\hline $\operatorname{Leu}\left(L_{2}\right)$ & 16,239 & 16,304 & 66 & & & TAA & 0 & $\mathrm{~L}$ \\
\hline $\operatorname{Tyr}(Y)$ & 16,305 & 16,373 & 69 & & & GTA & 8 & $\mathrm{H}$ \\
\hline $\operatorname{Trp}(W)$ & 16,382 & 16,450 & 69 & & & TCA & 0 & $\mathrm{~L}$ \\
\hline $\operatorname{Gln}(Q)$ & 16,451 & 16,515 & 65 & & & TTG & 8 & $\mathrm{~L}$ \\
\hline Cys $(C)$ & 16,524 & 16,590 & 67 & & & GCA & 1 & L \\
\hline
\end{tabular}

Table 2. Features of the mitochondrial genome of $D$. arrosors.

codon position (Fig. S5, Table S3). This result supports the hypothesis that the codon usage bias in PCGs and the AT bias of the third codon position are positively correlated ${ }^{54,55}$.

Comparative genomic analysis of Paguroidea species. Using the $P$. filholi mitogenome as the reference sequence, all available mitogenomes in the superfamily Paguroidea were compared using BRIG. The results reveal the gene rearrangement in 15 Paguroidea mitogenomes (Fig. 1). The mitogenomes of the family Paguridae are observed to be fairly conserved, with about $80 \%$ sequence identity in most regions (six innermost rings in Fig. 1). However, the mitogenomes of the species under the families Coenobitidae, Diogenidae, and Pylochelidae are quite different from the family Paguridae, as can be seen from the larger gap regions in the BRIG map (nine outermost rings in Fig. 1).

By using the Mauve analysis, we identified five large genomic homologous regions (marked A-E in Fig. 2). These homologous regions are commonly presented in all 15 Paguroidea mitogenomes. For the B region, it has the maximum length diversification and is greatly contributed to the genome size variation between Paguroidea mitogenomes (Fig. 2). In addition, we found that homologous regions $\mathrm{D}$ and $\mathrm{E}$ are rearranged in $D$. aspersus mitogenome. The two homologous regions show an E-D order in D. aspersus mitogenome, while the other hermit crabs display a D-E order (Fig. 2). 


\begin{tabular}{|c|c|c|c|c|c|c|c|c|}
\hline \multirow[b]{2}{*}{ Gene } & \multicolumn{2}{|c|}{ Position } & \multirow[b]{2}{*}{ Length (bp) } & \multirow[b]{2}{*}{ Amino acid } & \multirow[b]{2}{*}{ Start/stop codon } & \multirow[b]{2}{*}{ Anticodon } & \multirow[b]{2}{*}{ Intergenic region } & \multirow[b]{2}{*}{ Strand } \\
\hline & From & To & & & & & & \\
\hline $\mathrm{COI}$ & 1 & 1539 & 1539 & 512 & ATG/TAA & & -5 & $\mathrm{H}$ \\
\hline $\operatorname{Leu}\left(L_{1}\right)$ & 1535 & 1599 & 65 & & & TAG & 5 & $\mathrm{H}$ \\
\hline COII & 1605 & 2297 & 693 & 230 & ATG/TAG & & 8 & $\mathrm{H}$ \\
\hline Lys $(K)$ & 2306 & 2373 & 68 & & & TTT & 9 & $\mathrm{H}$ \\
\hline $\operatorname{Met}(M)$ & 2383 & 2449 & 67 & & & CAT & 7 & $\mathrm{H}$ \\
\hline Ile (I) & 2457 & 2523 & 67 & & & GAT & 51 & $\mathrm{H}$ \\
\hline$N D 2$ & 2575 & 3576 & 1002 & 333 & ATT/TAA & & 3 & $\mathrm{H}$ \\
\hline $\operatorname{Asp}(D)$ & 3580 & 3645 & 66 & & & GTC & 0 & $\mathrm{H}$ \\
\hline ATP8 & 3646 & 3804 & 159 & 52 & ATC/TAG & & -7 & $\mathrm{H}$ \\
\hline ATP6 & 3798 & 4472 & 675 & 224 & ATG/TAA & & -1 & $\mathrm{H}$ \\
\hline COIII & 4472 & 5263 & 792 & 263 & ATG/TAG & & 17 & $\mathrm{H}$ \\
\hline $\operatorname{Arg}(R)$ & 5281 & 5346 & 66 & & & TCG & 0 & $\mathrm{H}$ \\
\hline $\operatorname{Asn}(N)$ & 5347 & 5408 & 62 & & & GTT & 6 & $\mathrm{H}$ \\
\hline Glu $(E)$ & 5415 & 5480 & 66 & & & TTC & 163 & $\mathrm{H}$ \\
\hline $\operatorname{Thr}(T)$ & 5644 & 5711 & 68 & & & & 9 & $\mathrm{H}$ \\
\hline ND6 & 5721 & 6239 & 519 & & ATG/GAC & & -5 & $\mathrm{H}$ \\
\hline$C y t b$ & 6235 & 7371 & 1137 & & ATG/TAG & & -1 & $\mathrm{H}$ \\
\hline $\operatorname{Ser}\left(S_{2}\right)$ & 7371 & 7438 & 68 & & & & 3 & $\mathrm{H}$ \\
\hline Phe $(F)$ & 7442 & 7504 & 63 & & & GAA & 3 & $\mathrm{~L}$ \\
\hline ND5 & 7508 & 9233 & 1726 & 575 & GTG/T & & 0 & $\mathrm{~L}$ \\
\hline His $(H)$ & 9234 & 9299 & 66 & & & GTG & 87 & $\mathrm{~L}$ \\
\hline ND4 & 9387 & 10,790 & 1345 & 467 & ATG/TAA & & -7 & $\mathrm{~L}$ \\
\hline ND4L & 10,784 & 11,086 & 303 & 100 & ATG/TAA & & 176 & $\mathrm{~L}$ \\
\hline Pro $(P)$ & 11,263 & 11,329 & 67 & & & TGG & 2 & $\mathrm{~L}$ \\
\hline ND1 & 11,332 & 12,261 & 930 & 309 & ATC/TAA & & -1 & $\mathrm{~L}$ \\
\hline $16 S$ & 12,261 & 13,660 & 1400 & & & & 0 & $\mathrm{~L}$ \\
\hline $\operatorname{Val}(V)$ & 13,661 & 13,729 & 69 & & & TAC & 0 & $\mathrm{~L}$ \\
\hline $12 S$ & 13,730 & 14,530 & 801 & & & & 0 & $\mathrm{~L}$ \\
\hline $\mathrm{CR}$ & 14,531 & 15,991 & 1461 & & & & 0 & $\mathrm{H}$ \\
\hline $\operatorname{Ser}\left(S_{1}\right)$ & 15,992 & 16,054 & 63 & & & TCT & 6 & $\mathrm{~L}$ \\
\hline Ala $(A)$ & 16,061 & 16,125 & 65 & & & TGC & 8 & $\mathrm{~L}$ \\
\hline ND3 & 16,134 & 16,478 & 345 & 114 & TTG/TAG & & 6 & $\mathrm{~L}$ \\
\hline Gly $(G)$ & 16,485 & 16,550 & 66 & & & TTC & 9 & $\mathrm{~L}$ \\
\hline $\operatorname{Leu}\left(L_{2}\right)$ & 16,560 & 16,627 & 68 & & & TAA & 0 & $\mathrm{~L}$ \\
\hline $\operatorname{Tyr}(Y)$ & 16,628 & 16,697 & 70 & & & GTA & 8 & $\mathrm{H}$ \\
\hline $\operatorname{Trp}(W)$ & 16,706 & 16,775 & 70 & & & TCA & 0 & $\mathrm{~L}$ \\
\hline $\operatorname{Gln}(Q)$ & 16,776 & 16,838 & 63 & & & TTG & 9 & $\mathrm{~L}$ \\
\hline Cys $(C)$ & 16,848 & 16,914 & 67 & & & GCA & 1 & $\mathrm{~L}$ \\
\hline
\end{tabular}

Table 3. Features of the mitochondrial genome of $D$. asperses.

To estimate the evolutionary-selection constraints on 13 PCGs in the superfamily Paguroidea, we perform dN/ $\mathrm{dS}$ analysis for each PCG. The dN/dS ratios for all PCGs are less than 1, indicating that these genes are evolving primarily under purifying selection. Among them, the lowest $\mathrm{dN} / \mathrm{dS}$ value $(0.113)$ for COI gene indicates the strongest purifying selection, whereas the highest $\mathrm{dN} / \mathrm{dS}$ value (0.707) for ATP8 gene shows a highly relaxed purifying selection (Fig. 3). In general, the $\mathrm{dN} / \mathrm{dS}$ values indicate that the evolution of Paguroidea mitogenomes has been dominated by purifying selection. Besides, we conduct genetic distance analysis for 13 PCGs. COI gene possesses the least genetic distance (average 0.237), and ND6 gene captures the largest value (average 0.494), representing the most conserved and variable genes, respectively (Fig. 3).

Mitochondrial gene order and rearrangements. The gene arrangement in the mitogenomes of $D$. arrosor and $D$. aspersus is shown in Fig. 4. The gene order of the two mitogenomes belonging to the same genus is different. Compared with the gene order in ancestral crustaceans (the pancrutacean ground pattern) mitogenomes ${ }^{56}$, the gene order in $D$. arrosor and $D$. aspersus mitogenomes underwent large-scale gene rearrangements. For $D$. arrosor, at least six gene clusters (or genes) significantly differ from the typical order, involving 12 tRNAs $\left(L_{2}, G, A, S_{1}, P, L_{1}, I, Q, M, W, C\right.$, and $\left.Y\right)$, and two PCGs (ND3 and ND2). Of these six gene rearrangements, a single $L_{2}$ is inverted from the downstream of $C O I$ in the $\mathrm{H}$-strand to downstream of the $G$ in the 


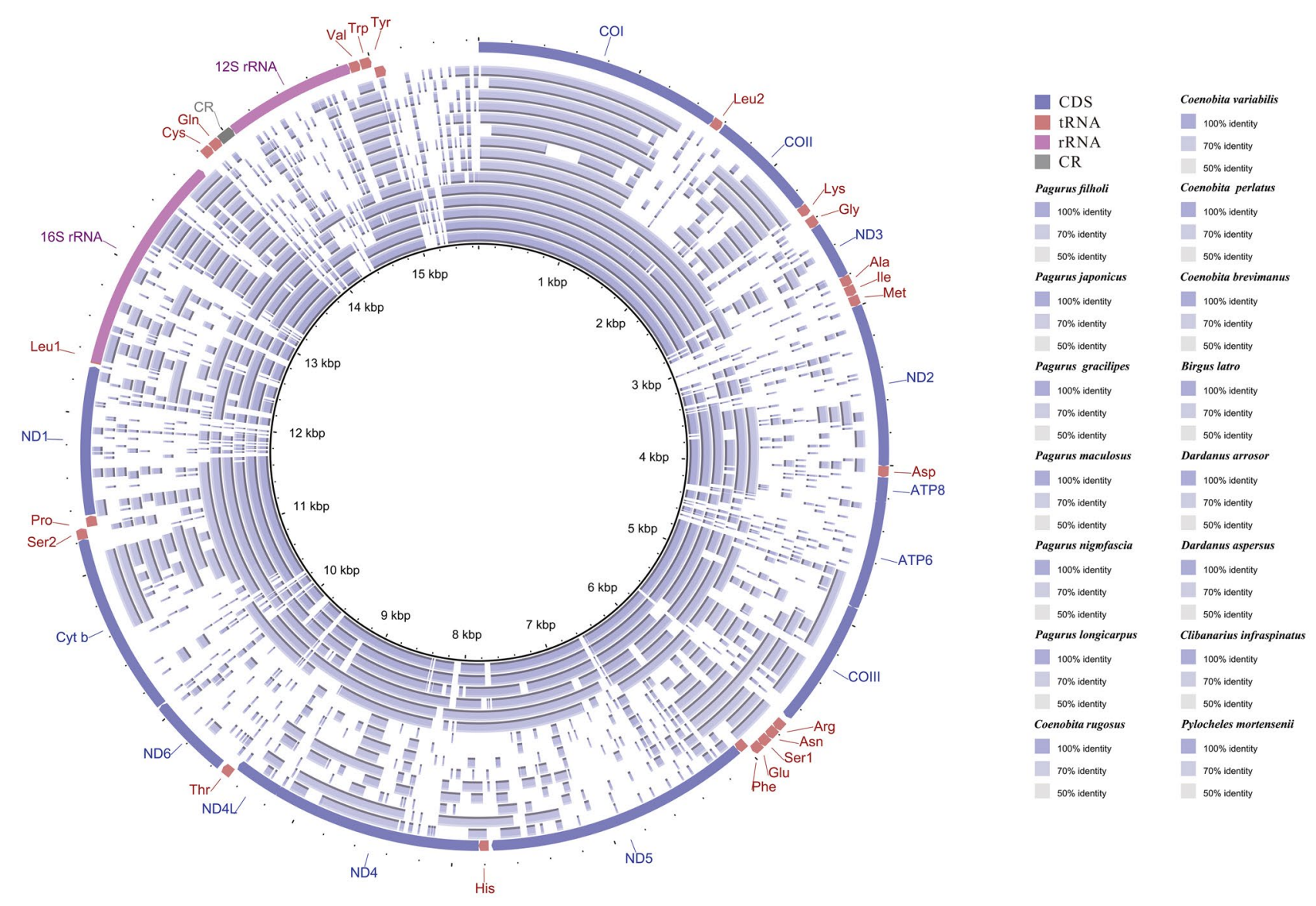

Figure 1. BLAST comparison of all Paguroidea mitogenomes against a reference ( $P$. filholi) generated by Blast Ring Image Generator (BRIG). The intensity of the ring color denotes the degree of sequence conservation at that region. Gaps in rings correspond to regions with less than $50 \%$ identity to the reference sequence. The innermost ring to the outermost in this figure is presented as follows: P. filholi, P. japonicus, P. gracilipes, $P$. maculosus, P. nigrofascia, P. longicarpus, Coenobita rugosus, C. variabilis, C. perlatus, C. brevimanus, Birgus latro, D. arrosor, D. aspersus, Clibanarius infraspinatus, and P. mortensenii.

L-strand (Fig. 4A(1)). The G- ND3- $A-S_{1}$ cluster is inverted from the downstream of COIII in the H-strand to downstream of the CR in the L-strand (Fig. 4A(2)). A single $P$ moves from the downstream of $T$ to downstream of the $S_{2}$ (Fig. 4A(3)). A single $L_{1}$ is inverted from the downstream of $N D 1$ in the L-strand to downstream of the $C O I$ in the H-strand (Fig. 4A(4)). The $I-Q-M-N D 2$ cluster is divided into two sections, one (I, $M$, and ND2) is shifted to downstream of $K$. The other $(Q)$ is shifted to the end of the linear mitogenome (Fig. 4A(5)). The $W$ - $C$ $Y$ cluster order is changed into $Y$ - $W$ - $C$ order (Fig. 4A(6)). For D. aspersus, there are also at least six gene clusters (or genes) that differ significantly from the typical order, but the genes involved are different from $D$. arrosor. The rearrangement process involves 14 tRNAs $\left(L_{2}, G, A, S_{1}, T, P, S_{2}, L_{1}, I, Q, M, W, C\right.$, and $Y$ ), and four PCGs (ND3, ND6, Cyt b, and ND2). Relative to the gene arrangement of D. arrosor mitogenome, the T- P-ND6-Cyt $b$ - $S_{2}$ cluster is divided into two sections, one $\left(T, N D 6, C y t b\right.$, and $\left.S_{2}\right)$ is shifted to downstream of $E$. The other $(P)$ is shifted to downstream of ND4L (Fig. 4A(3)). Based on the CREx analysis, transposition, reversal, and TDRL may be involved in the large-scale gene rearrangements in D. arrosor and D. aspersus mitogenomes (Figs. S6, S7).

The 15 hermit crabs exhibit six types of gene organization (Fig. 5). The mitogenomes of the family Paguridae possess three types of gene order (Type I, Type II, and Type III in Fig. 5). Relative to the remaining three types of gene order (Type IV, Type V, and Type VI in Fig. 5), these three types of gene order are more similar. The mitogenomes of the family Diogenidae possess two types of gene order (Type IV and Type V in Fig. 5). Only the gene arrangement of one gene cluster $\left(T-N D 6-C y t b-S_{2}\right)$ is found to be different between the two gene orders. For the remaining two families, Coenobitidae and Pylochelidae, each has only one type of gene order (Type IV and Type VI in Fig. 5). Among them, Coenobitidae shares one of the two gene orders of Diogenidae (Type IV). These results are consistent with the conclusion from the gene order-based phylogenetic tree (Fig. 5). In the gene order tree, all Paguridae species cluster into a clade, showing the closest relationship (Clade I). Species of the family Coenobitidae and Diogenidae are clustered together as a group (Clade II). As the only representative of the family Pylochelidae (Clade III), P. mortensenii forms a seperate branch. Our results support that comparisons of mitochondrial gene rearrangements, to some extent, are a useful tool for phylogenetic studies. 


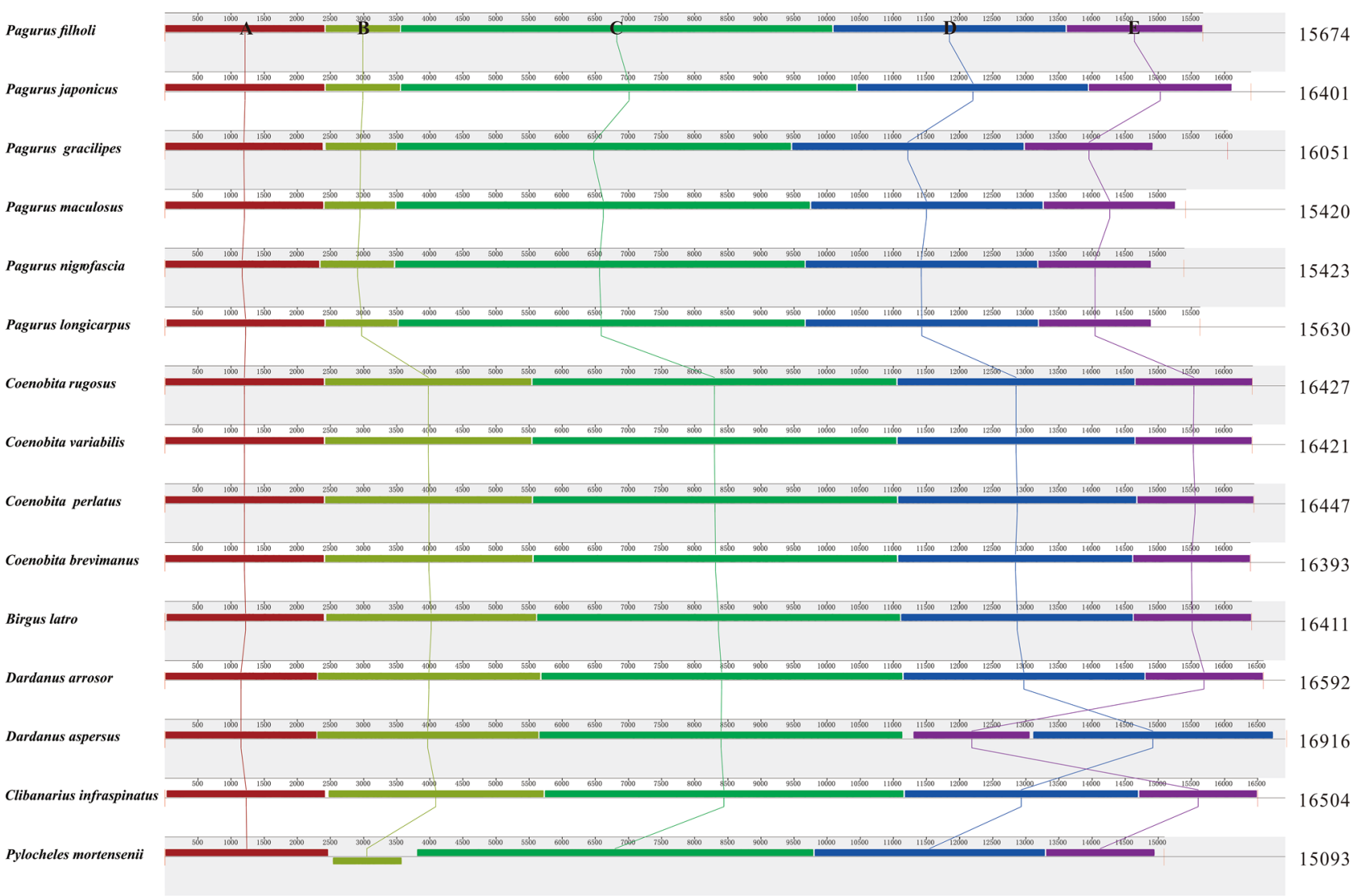

Figure 2. Multiple genome alignments of 15 hermit crabs. The mitogenome of $P$. filholi is shown at the top as the reference genome. All genomes are started from the Pro gene. The ruler at the top of each genome shows nucleotide positions. Within each of the alignments, local collinear blocks are represented by blocks of the same color connected by lines.

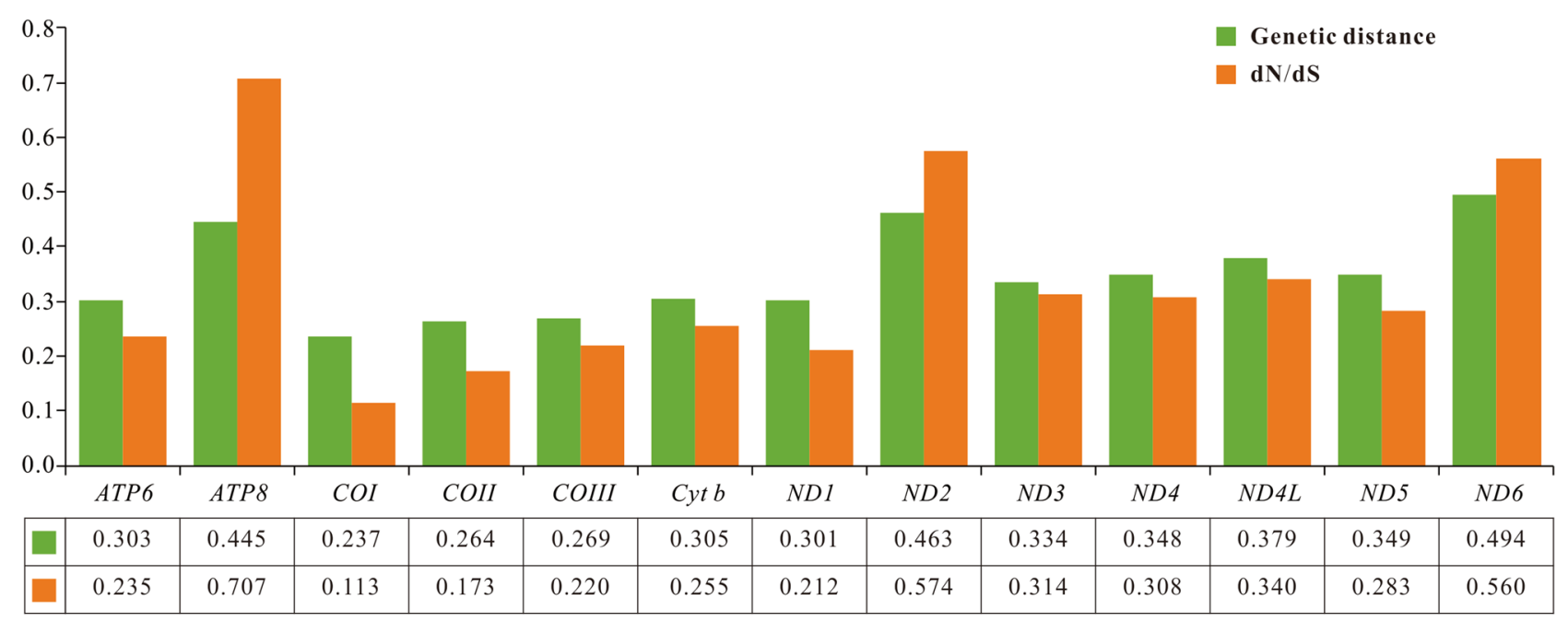

Gene

Figure 3. Genetic distance (on average) and dN/dS substitution rates of 13 PCGs among 15 hermit crabs.

Phylogenetic analysis. In the present study, the phylogenetic relationships among Paguroidea were reconstructed based on the nucleotide sequences of 13 PCGs using maximum likelihood (ML) and Bayesian (BI) methods. The phylogenetic trees (ML tree and BI tree) show an identical topology; thus, only one topology (BI) with both support values is displayed (Fig. 6). The results show that D. arrosor and D. aspersus are most closely related, forming part of the family Diogenidae. Three Diogenidae species are separated into two clades, two 
A)
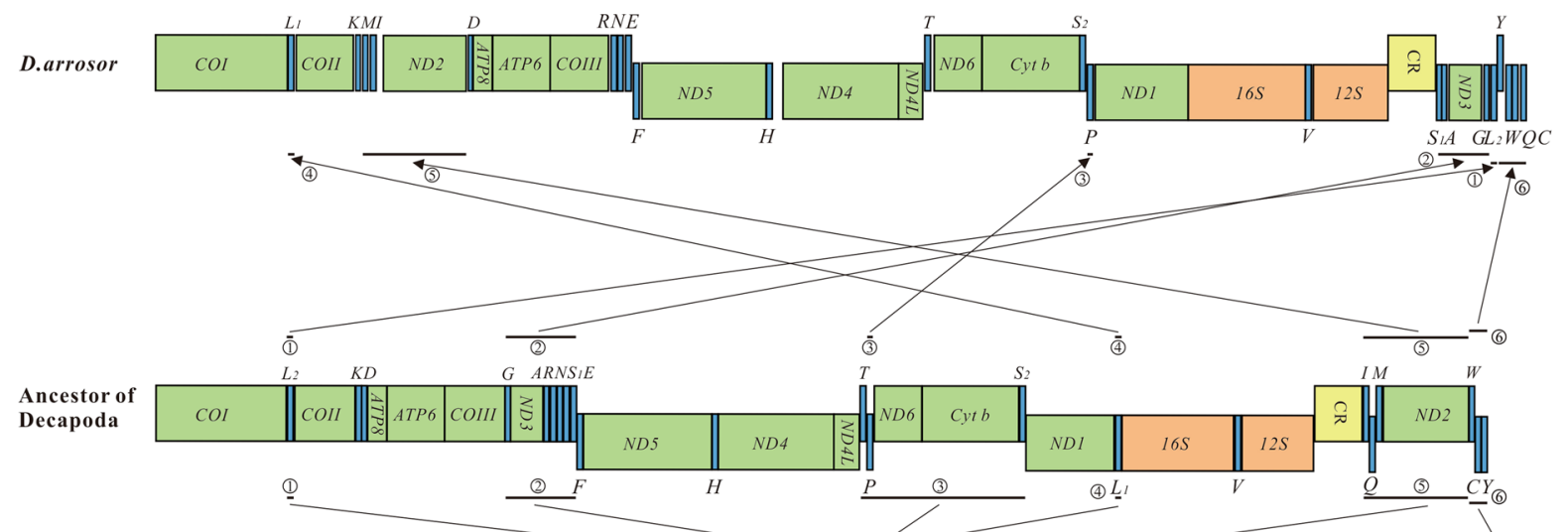

B)

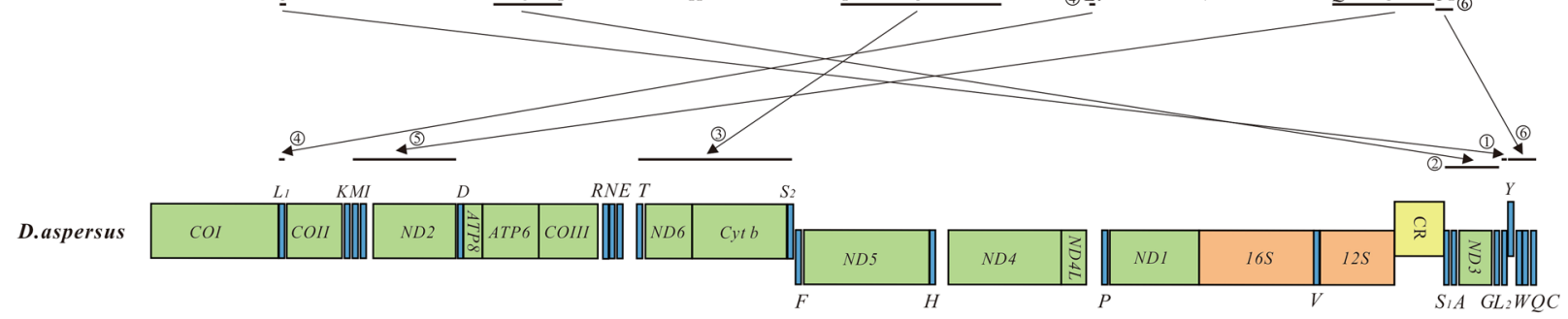

Figure 4. (A) Gene rearrangements in D. arrosor mitogenome; (B) Gene rearrangements in D. aspersus mitogenome.

Dardanus species cluster together as a clade, and then form a sister group with five Coenobitidae species. While the remaining one (Clibanarius infraspinatus) forms a separate clade, resulting in the paraphyly of Diogenidae. Besides, of the four families included in the phylogenetic tree, almost all families except Diogenidae form a monophyletic clade. However, the paraphyly of the family Pylochelidae was originally proposed by Richter and $\mathrm{Scholtz}^{57}$ and has been confirmed by many previous researches ${ }^{58,59}$. Since there is only one representative of the family Pylochelidae in our study, the monophyly of this taxon should be treated with caution.

\section{Discussion}

In the present study, our phylogenetic reconstruction based on the nucleotide sequences of 13 PCGs recovered a robust tree (Fig. 6). For a long time, the phylogenetic status of Diogenidae has been controversial. Most previous researches based on morphological features considered it to be a paraphyletic clade. But Forest ${ }^{60,61}$ suggested that the family Diogenidae is an ancient monophyletic group. In recent years, an increasing number of molecular studies, including ours, have supported the paraphyly of this taxon. For example, Tsang et al.s used two nuclear protein genes to conduct phylogenetic inference and clearly pointed out that the family Diogenidae is a paraphyletic clade ${ }^{62}$. In their study, the genus Coenobita (Coenobitidae) is embedded within the branch of the family Diogenidae. Based on mitochondrial gene sequences, Landschoff and Gouws's research recovered the paraphyly of the family Diogenidae as well ${ }^{63}$. However, there are few studies on the phylogenetic relationships among the genera of the family Diogenidae. Previous studies mainly focused on exploring the phylogenetic relationships of the infraorder Anomura, involving only a few genera and species of the family Diogenidae. Accordingly, increased taxon sampling is required to conclusively resolve the phylogenetic relationships within the family Diogenidae and the superfamily Paguroidea.

Besides, we reconstructed the phylogeny of Paguroidea based on the gene order (Fig. 5). In the family-level relationships within Paguroidea, the gene order information seems to be reliable for phylogenetic inference. A good illustration is that the monophyly of three families (Paguridae, Coenobitidae, and Pylochelidae) and the paraphyly of the family Diogenidae are reconfirmed in the gene order tree (Figs. 5, 6). Our conclusion is in accordance with previous workers, who suggested that gene rearrangements, to some extent, contain phylogenetic information. For example, Shao et al. ${ }^{64}$ compared the mitochondrial gene arrangements of 12 anomurans and found that Munidopsis lauensis and M. verrilli are most closely related to Shinkaia crosnieri. Based on the comparative analysis of mitochondrial gene arrangement within Coleoidea, Akasaki et al ${ }^{65}$ concluded that order Octopoda might be the most ancestral among this subclass Coleoidea. However, the potential to resolve the phylogenetic relationships within families based on gene order alone is clearly inferior to sequence-based approaches. One example is that the monophyly of two genera (Dardanus and Coenobita) is not recovered in the gene order tree (Fig. 5). In future studies, it may be possible to resolve some long-standing phylogenetic controversies by integrating gene order and sequence data.

For most families of the order Decapoda, congeners belonging to the same family share the same gene arrangement generally. Accordingly, it is acceptable to apply gene rearrangement as a molecular marker for phylogenetic inference $\mathrm{c}^{6,15,16}$. However, there are some exceptions. For example, the family Camptandriidae Stimpson, 1858 possess two different gene arrangements (unpublished), and the freshwater crabs Potamidae Ortmann, 1896 possess at least nine main types of gene rearrangement ${ }^{66}$. In the present study, we even found that two closely related species of the genus Dardanus capture different gene rearrangements. These examples challenge the 

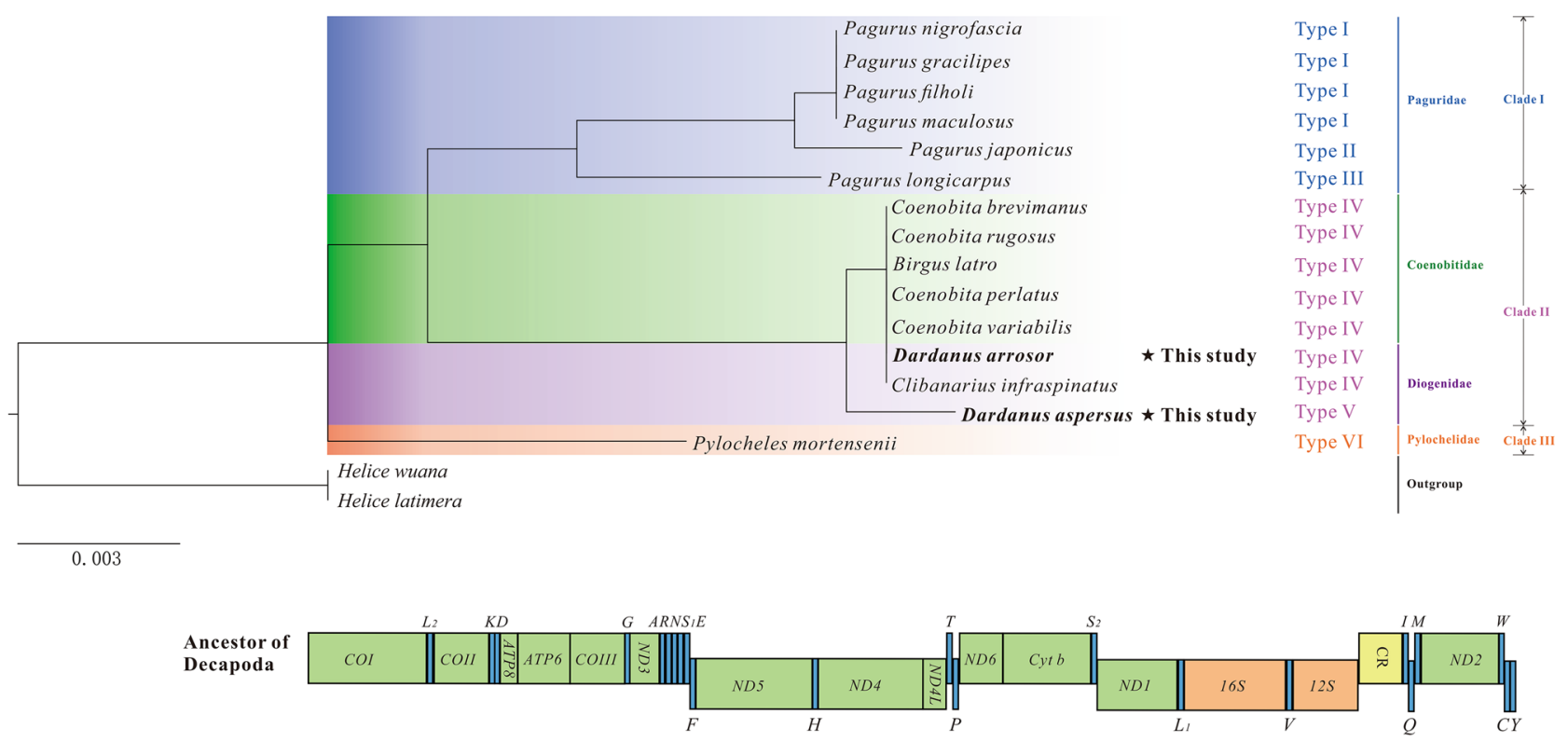

Type I

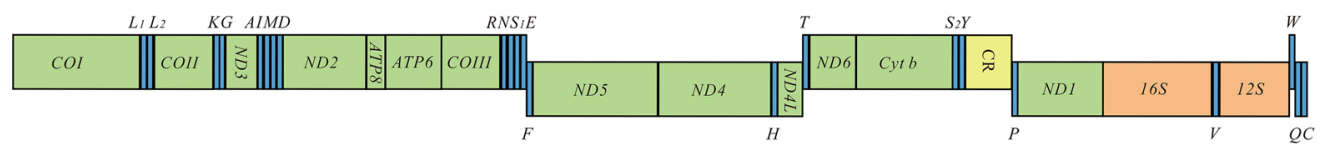

Clade I

Type II

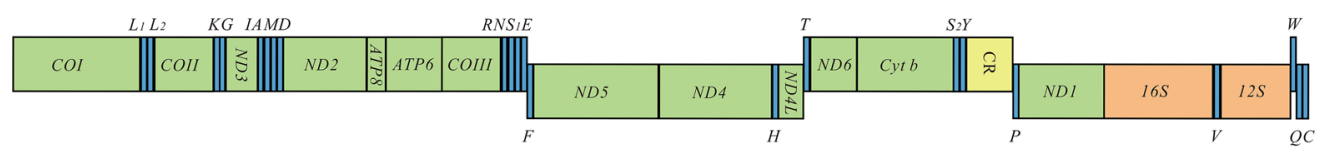

Type III

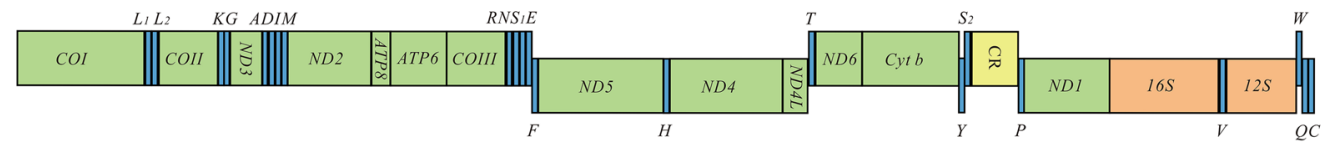

Type IV

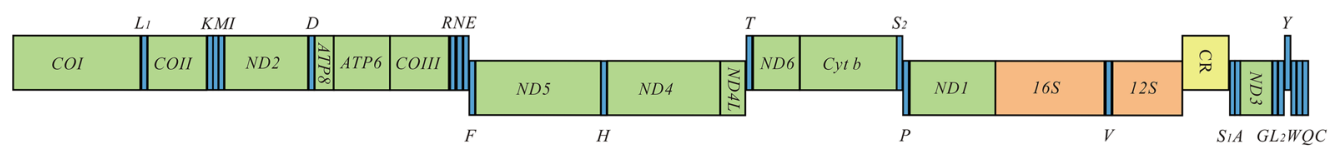

Clade II
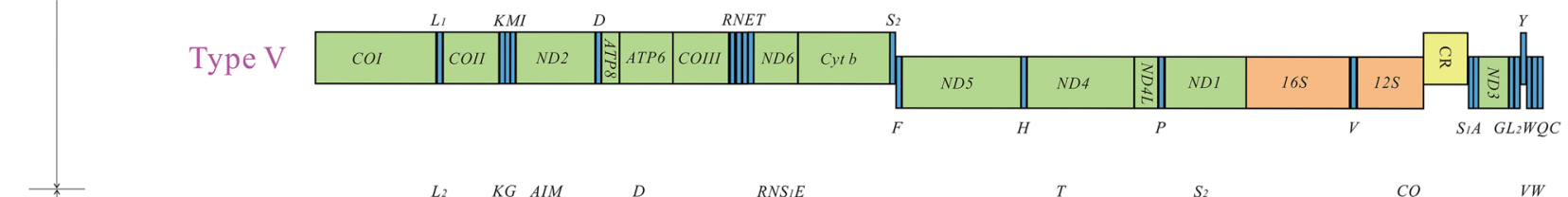

Clade III

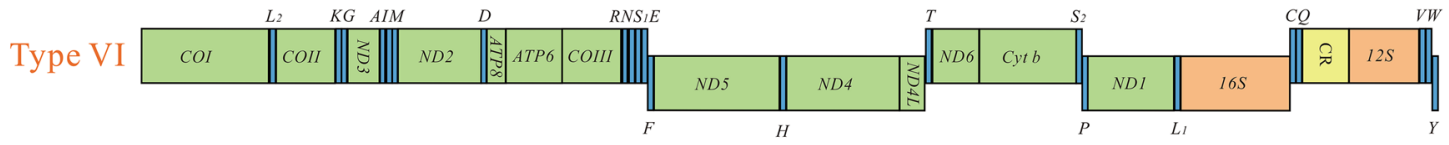

Figure 5. Phylogeny of Paguroidea reconstructed using gene order data, and arrangement of mitochondrial genes in the ancestral pancrustacean pattern and the superfamily Paguroidea. PCGs and CR are indicated with boxes, and tRNAs are indicated with columns. COI has been designated the start point for the linear representation of the gene arrangement.

utility of gene rearrangement as a molecular marker in phylogenetic studies. So it triggers a thought-provoking question that why the mitogenome gene arrangement differs between very closely related species? One possible hypothesis is that the mitogenome gene rearrangement is a continuous and dynamic process and may occur very recently even after speciation events. In future studies, more relevant data are essential to verify this hypothesis. 


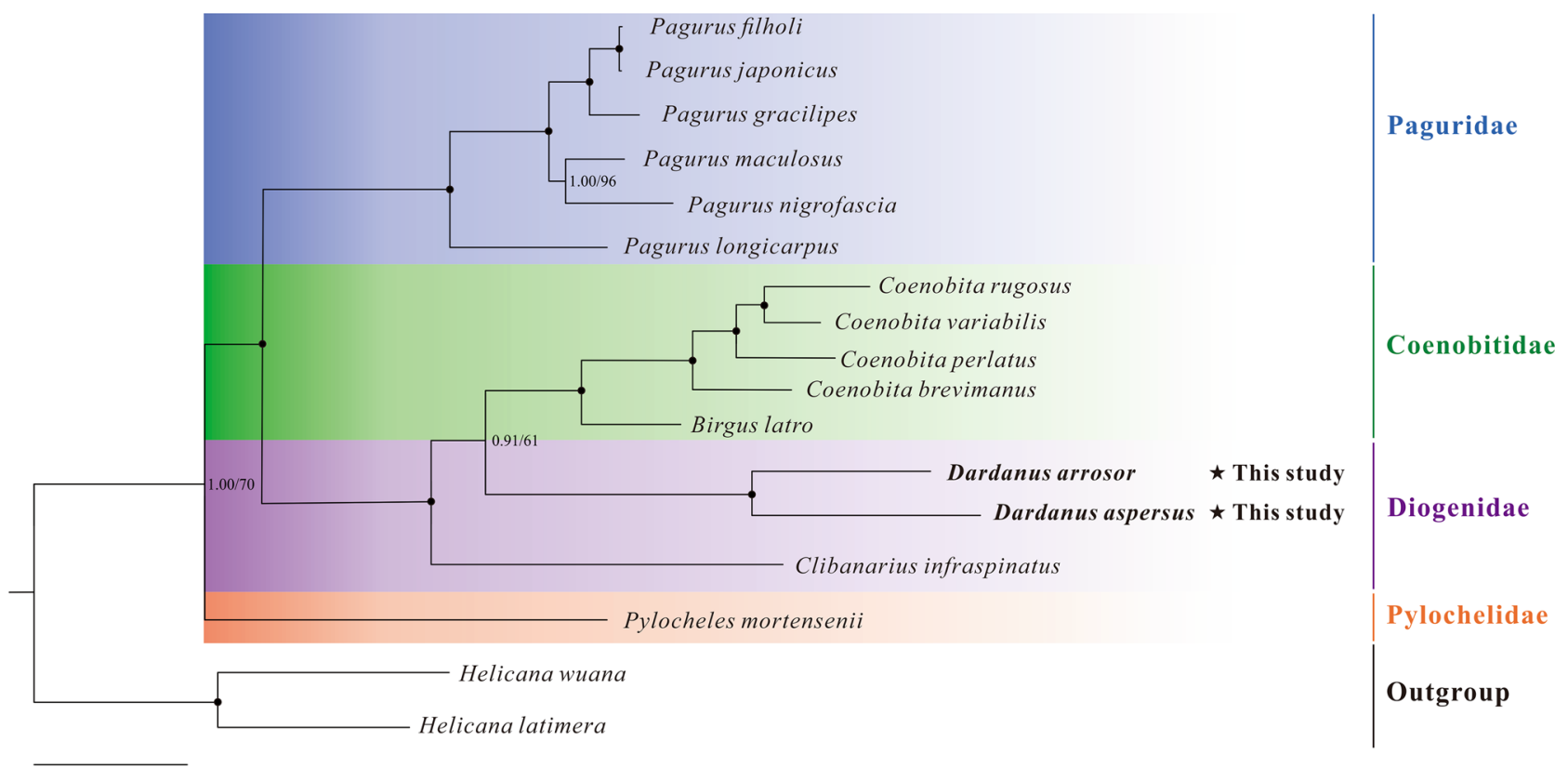

Figure 6. Phylogenetic tree of Paguroidea species inferred from the nucleotide sequences of 13 PCGs based on Bayesian inference (BI) and maximum likelihood (ML) analysis. Node marked with a solid circle indicates 100 maximum likelihood bootstrap value and $100 \%$ supporting value.

\section{Conclusion}

In the present study, we reported the mitogenomes of $D$. arrosor and D. aspersus, supplementing the limited mitogenome information of the family Diogenidae (Anomura: Paguroidea). By analyzing the mitogenomes of $D$. arrosor and $D$. aspersus and comparing them with other published Paguroidea mitogenomes, we can draw the following conclusions: (a) the gene content of the two mitogenomes belonging to the same genus is conserved, whereas the gene arrangement is different; (b) CREx analysis reveals that transposition, reversal, and TDRL may be involved in the large-scale gene rearrangements in D. arrosor and D. aspersus mitogenomes; (c) the $\mathrm{dN} / \mathrm{dS}$ analysis indicates that the evolution of Paguroidea mitogenomes has been dominated by purifying selection; (d) the phylogenetic analyses based on both gene order and sequence data reveal the monophyly of three families (Paguridae, Coenobitidae, and Pylochelidae) and the paraphyly of the family Diogenidae. In future studies, large-scale taxonomic samplings are still needed to further investigate the taxonomical and phylogenetic studies of Paguroidea.

Received: 30 July 2021; Accepted: 11 October 2021

Published online: 08 November 2021

\section{References}

1. Boore, J. L. Animal mitochondrial genomes. Nucl. Acids Res. 27, 1767-1780 (1999).

2. Gyllensten, U., Wharton, D., Josefsson, A. \& Wilson, A. C. Paternal inheritance of mitochondrial DNA in mice. Nature 352, 255-257 (1991).

3. Sato, M. \& Sato, K. Maternal inheritance of mitochondrial DNA by diverse mechanisms to eliminate paternal mitochondrial DNA. Biochim. Biophys. Acta (BBA) Mol. Cell Res. 1833, 1979-1984 (2013).

4. Sanchez, G. et al. Population genetics of the jumbo squid Dosidicus gigas (Cephalopoda: Ommastrephidae) in the northern Humboldt Current system based on mitochondrial and microsatellite DNA markers. Fish. Res. 175, 1-9. https://doi.org/10.1016/j.fishr es.2015.11.005 (2016).

5. Ma, Z. et al. Comparative mitogenomics of the genus Odontobutis (Perciformes: Gobioidei: Odontobutidae) revealed conserved gene rearrangement and high sequence variations. Int. J. Mol. Sci. 16, 25031-25049. https://doi.org/10.3390/ijms161025031 (2015).

6. Tan, M. H. et al. ORDER within the chaos: Insights into phylogenetic relationships within the Anomura (Crustacea: Decapoda) from mitochondrial sequences and gene order rearrangements. Mol. Phylogenet. Evol. 127, 320-331. https://doi.org/10.1016/j. ympev.2018.05.015 (2018).

7. Ren, L. et al. Comparative analysis of mitochondrial genomes among the subfamily Sarcophaginae (Diptera: Sarcophagidae) and phylogenetic implications. Int. J. Biol. Macromol. 161, 214-222 (2020).

8. Chen, L.-P. et al. Comparative analysis of mitogenomes among six species of grasshoppers (Orthoptera: Acridoidea: Catantopidae) and their phylogenetic implications in wing-type evolution. Int. J. Biol. Macromol. 159, 1062-1072 (2020).

9. Jiang, L., Kang, L., Wu, C., Chen, M. \& Lü, Z. A comprehensive description and evolutionary analysis of 9 Loliginidae mitochondrial genomes. Hydrobiologia 808, 115-124 (2018).

10. Wu, X. et al. New features of Asian Crassostrea oyster mitochondrial genomes: A novel alloacceptor tRNA gene recruitment and two novel ORFs. Gene 507, 112-118. https://doi.org/10.1016/j.gene.2012.07.032 (2012).

11. Liu, Q. N. et al. A transfer RNA gene rearrangement in the lepidopteran mitochondrial genome. Biochem. Biophys. Res. Commun. 489, 149-154. https://doi.org/10.1016/j.bbrc.2017.05.115 (2017). 
12. Zhang, Y. et al. Gene rearrangements in the mitochondrial genome of Chiromantes eulimene (Brachyura: Sesarmidae) and phylogenetic implications for Brachyura. Int. J. Biol. Macromol. 162, 704-714. https://doi.org/10.1016/j.ijbiomac.2020.06.196 (2020).

13. Gong, L. et al. Large-scale mitochondrial gene rearrangements in the hermit crab Pagurus nigrofascia and phylogenetic analysis of the Anomura. Gene 695, 75-83. https://doi.org/10.1016/j.gene.2019.01.035 (2019).

14. Yuan, Y., Li, Q., Yu, H. \& Kong, L. The complete mitochondrial genomes of six heterodont bivalves (Tellinoidea and Solenoidea): Variable gene arrangements and phylogenetic implications. PLoS ONE 7, e32353 (2012).

15. Smith, M. J., Arndt, A., Gorski, S. \& Fajber, E. The phylogeny of echinoderm classes based on mitochondrial gene arrangements. J. Mol. Evol. 36, 545-554 (1993).

16. Morrison, C. et al. Mitochondrial gene rearrangements confirm the parallel evolution of the crab-like form. Proc. R. Soc. Lond. Ser. B Biol. Sci. 269, 345-350 (2002).

17. Macey, J. R., Larson, A., Ananjeva, N. B., Fang, Z. \& Papenfuss, T. J. Two novel gene orders and the role of light-strand replication in rearrangement of the vertebrate mitochondrial genome. Mol. Biol. Evol. 14, 91-104 (1997).

18. Thyagarajan, B., Padua, R. A. \& Campbell, C. Mammalian mitochondria possess homologous DNA recombination activity. J. Biol. Chem. 271, 27536-27543 (1996).

19. Tsaousis, A. D., Martin, D., Ladoukakis, E., Posada, D. \& Zouros, E. Widespread recombination in published animal mtDNA sequences. Mol. Biol. Evol. 22, 925-933 (2005).

20. Zhuang, X. \& Cheng, C. H. C. ND6 gene "lost" and found: Evolution of mitochondrial gene rearrangement in Antarctic notothenioids. Mol. Biol. Evol. 27, 1391-1403 (2010).

21. Moritz, C. \& Brown, W. M. Tandem duplications in animal mitochondrial DNAs: Variation in incidence and gene content among lizards. Proc. Natl. Acad. Sci. U. S. A. 84, 7183-7187 (1987).

22. Cantatore, P., Gadaleta, M., Roberti, M., Saccone, C. \& Wilson, A. Duplication and remoulding of tRNA genes during the evolutionary rearrangement of mitochondrial genomes. Nature 329, 853-855 (1987).

23. Poulton, J. et al. Families of mtDNA re-arrangements can be detected in patients with mtDNA deletions: Duplications may be a transient intermediate form. Hum. Mol. Genet. 2, 23-30 (1993).

24. Lavrov, D. V., Boore, J. L. \& Brown, W. M. Complete mtDNA sequences of two millipedes suggest a new model for mitochondrial gene rearrangements: Duplication and nonrandom loss. Mol. Biol. Evol. 19, 163-169 (2002).

25. De Grave, S. et al. A classification of living and fossil genera of decapod crustaceans. Raffles Bull. Zool. 21 Supplement, 1-109 (2009).

26. UDEKEM, D. A. C. D. Inventaire et distribution des crustacés décapodes de l'Atlantique nord-oriental, de la Méditerranée et des eaux continentales adjacentes au nord de 25 N. Collection des Patrimoines Naturels 40, 1-383 (1999).

27. Sha, Z., Xiao, L. \& Wang, Y. Study on the Taxonomy of the Family Diogenidae (Crustacea: Decapoda: Anomura: Paguridea) from China Seas (Science Press, 2015).

28. McLaughlin, P. A. Illustrated keys to families and genera of the superfamily Paguroidea (Crustacea: Decapoda: Anomura), with diagnoses of genera of Paguridae. Mem. Mus. Vic. 60, 111-144 (2003).

29. McLaughlin, P. A. \& Lemaitre, R. Carcinization in the Anomura-fact or fiction? I. Evidence from adult morphology. Contrib. Zool. 67, 79-123 (1997).

30. McLaughlin, P. A., Lemaitre, R. \& Sorhannus, U. Hermit crab phylogeny: A reappraisal and its "fall-out". J. Crustac. Biol. 27, 97-115 (2007).

31. Reshmi, R. \& Bijukumar, A. New report of the hermit crabs Dardanus lagopodes (Forskal, 1775), Paguristes miyakei Forest \& McLaughlin, 1998 and Oncopagurus monstrosus (Alcock, 1894) (Crustacea: Decapoda: Anomura) from the Indian coast. Rec. Zool. Surv. India 113, 197-201 (2013).

32. Deval, M. C. \& Froglia, C. New records of deep-sea decapod crustaceans in the Turkish Mediterranean Sea (North Levant Sea). Zool. Middle East 62, 323-330 (2016).

33. Martin, M. Cutadapt removes adapter sequences from high-throughput sequencing reads. EMBnet. J. 17, 10-12 (2011).

34. Dierckxsens, N., Mardulyn, P. \& Smits, G. NOVOPlasty: De novo assembly of organelle genomes from whole genome data. Nucl. Acids Res. 45, e18. https://doi.org/10.1093/nar/gkw955 (2017).

35. Bernt, M. et al. MITOS: Improved de novo metazoan mitochondrial genome annotation. Mol. Phylogenet. Evol. 69, 313-319 (2013).

36. Lowe, T. M. \& Chan, P. P. tRNAscan-SE on-line: Integrating search and context for analysis of transfer RNA genes. Nucl. Acids Res 44, W54-W57. https://doi.org/10.1093/nar/gkw413 (2016).

37. Alikhan, N.-F., Petty, N. K., Zakour, N. L. B. \& Beatson, S. A. BLAST Ring Image Generator (BRIG): Simple prokaryote genome comparisons. BMC Genom. 12, 1-10 (2011).

38. Kumar, S., Stecher, G., Li, M., Knyaz, C. \& Tamura, K. MEGA X: Molecular evolutionary genetics analysis across computing platforms. Mol. Biol. Evol. 35, 1547-1549 (2018).

39. Perna, N. T. \& Kocher, T. D. Patterns of nucleotide composition at fourfold degenerate sites of animal mitochondrial genomes. J. Mol. Evol. 41, 353-358 (1995).

40. Darling, A. C., Mau, B., Blattner, F. R. \& Perna, N. T. Mauve: Multiple alignment of conserved genomic sequence with rearrangements. Genome Res. 14, 1394-1403 (2004).

41. Bernt, M. et al. CREx: Inferring genomic rearrangements based on common intervals. Bioinformatics 23, 2957-2958 (2007).

42. Hu, F., Lin, Y. \& Tang, J. MLGO: Phylogeny reconstruction and ancestral inference from gene-order data. BMC Bioinform. 15, 1-6 (2014).

43. Zhang, D. et al. PhyloSuite: An integrated and scalable desktop platform for streamlined molecular sequence data management and evolutionary phylogenetics studies. Mol. Ecol. Resour. 20, 348-355. https://doi.org/10.1111/1755-0998.13096 (2020).

44. Katoh, K., Misawa, K., Kuma, K. I. \& Miyata, T. MAFFT: A novel method for rapid multiple sequence alignment based on fast Fourier transform. Nucl. Acids Res. 30, 3059-3066 (2002).

45. Talavera, G. \& Castresana, J. Improvement of phylogenies after removing divergent and ambiguously aligned blocks from protein sequence alignments. Syst. Biol. 56, 564-577 (2007).

46. Nguyen, L.-T., Schmidt, H. A., Von Haeseler, A. \& Minh, B. Q. IQ-TREE: A fast and effective stochastic algorithm for estimating maximum-likelihood phylogenies. Mol. Biol. Evol. 32, 268-274 (2015).

47. Ronquist, F. et al. MrBayes 3.2: Efficient Bayesian phylogenetic inference and model choice across a large model space. Syst. Biol. 61, 539-542. https://doi.org/10.1093/sysbio/sys029 (2012).

48. Sultana, Z. et al. Molecular phylogeny of ten intertidal hermit crabs of the genus Pagurus inferred from multiple mitochondrial genes, with special emphasis on the evolutionary relationship of Pagurus lanuginosus and Pagurus maculosus. Genetica 146, 369-381 (2018).

49. Hickerson, M. \& Cunningham, C. Dramatic mitochondrial gene rearrangements in the hermit crab Pagurus longicarpus (Crustacea, Anomura). Mol. Biol. Evol. 17, 639-644 (2000).

50. Gong, L. et al. Novel gene rearrangement in the mitochondrial genome of Coenobita brevimanus (Anomura: Coenobitidae) and phylogenetic implications for Anomura. Genomics 112, 1804-1812. https://doi.org/10.1016/j.ygeno.2019.10.012 (2020).

51. Veldsman, W. P., Wang, Y., Niu, J., Baeza, J. A. \& Chu, K. H. Characterization of the complete mitochondrial genome of a coconut crab, Birgus latro (Linnaeus, 1767) (Decapoda: Anomura: Coenobitidae), from Okinawa, Japan. J. Crustac. Biol. 40, 390-400 (2020). 
52. Gan, H. Y., Gan, H. M., Tan, M. H., Lee, Y. P. \& Austin, C. M. The complete mitogenome of the hermit crab Clibanarius infraspinatus (Hilgendorf, 1869), (Crustacea; Decapoda; Diogenidae)-A new gene order for the Decapoda. Mitochondrial DNA Part A 27, 4099-4100 (2016).

53. Wang, Q. et al. Comparative mitochondrial genomic analysis of Macrophthalmus pacificus and insights into the phylogeny of the Ocypodoidea \& Grapsoidea. Genomics 112, 82-91 (2020).

54. Kim, M. I. et al. Complete nucleotide sequence and organization of the mitogenome of the red-spotted apollo butterfly, Parnassius bremeri (Lepidoptera: Papilionidae) and comparison with other lepidopteran insects. Mol. Cells 28, 347-363 (2009).

55. Hao, J. et al. The complete mitochondrial genome of Ctenoptilum vasava (Lepidoptera: Hesperiidae: Pyrginae) and its phylogenetic implication. Comp. Funct. Genom. 2012, 328049 (2012).

56. Boore, J. L., Lavrov, D. V. \& Brown, W. M. Gene translocation links insects and crustaceans. Nature 392, 667-668 (1998).

57. Richter, S. \& Scholz, G. Morphological evidence for a hermit crab ancestry of lithodids (Crustace, Decapoda, Anomala, Paguroidea). Zool. Anz. 233, 187-187 (1994).

58. Lemaitre, R., Mclaughlin, P. A. \& Sorhannus, U. Phylogenetic relationships within the Pylochelidae (Decapoda: Anomura: Paguroidea): A cladistic analysis based on morphological characters. Zootaxa 2022, 1-14 (2009).

59. Lemaitre, R. \& McLaughlin, P. A. Recent advances and conflicts in concepts of anomuran phylogeny (Crustacea: Malacostraca). Arthropod Syst. Phylogeny. 67, 119-135 (2009).

60. Forest, J. Crustacea Decapoda Anomura: Révision du genre Trizopagurus Forest, 1952 (Diogenidae), avec rétablissement de deux genres nouveaux. Mémoires du Muséum national d'Histoire naturelle. Série A, Zoologie. 163, 9-149 (1995).

61. Forest, J. Révision du genre Aniculus (Decapoda Diogenidae). Crustaceana 8, 1-91 (1984).

62. Tsang, L., Ma, K., Ahyong, S., Chan, T.-Y. \& Chu, K. Phylogeny of Decapoda using two nuclear protein-coding genes: Origin and evolution of the Reptantia. Mol. Phylogenet. Evol. 48, 359-368 (2008).

63. Landschoff, J. \& Gouws, G. DNA barcoding as a tool to facilitate the taxonomy of hermit crabs (Decapoda: Anomura: Paguroidea). J. Crustac. Biol. 38, 780-793 (2018).

64. Sun, S. E., Sha, Z. \& Wang, Y. The complete mitochondrial genomes of two vent squat lobsters, Munidopsis lauensis and M. verrilli: Novel gene arrangements and phylogenetic implications. Ecol. Evol. 9, 12390-12407 (2019).

65. Akasaki, T. et al. Extensive mitochondrial gene arrangements in coleoid Cephalopoda and their phylogenetic implications. Mol. Phylogenet. Evol. 38, 648-658 (2006).

66. Zhang, Z. et al. Phylogenetic implications of mitogenome rearrangements in East Asian potamiscine freshwater crabs (Brachyura: Potamidae). Mol. Phylogenet. Evol. 143, 106669 (2020).

\section{Acknowledgements}

This work was supported by the Natural Science Foundation of Zhejiang Province (LY21C190007), Basic Scientific Research Operating Expenses of Zhejiang Provincial Universities (2021JZ003), Zhoushan Science and Technology Bureau (2021C21007) and Open Foundation from Marine Sciences in the First-Class Subjects of Zhejiang.

\section{Author contributions}

Y.Z. and L.M. conceived and designed the research. Y.Z., L.W., X.L., B.L., L.L., Z.L., and Y.G. conducted experiments and analyzed data. Z.Y. and L.G. wrote the manuscript. All authors read and approved the final version of the manuscript.

\section{Competing interests}

The authors declare no competing interests.

\section{Additional information}

Supplementary Information The online version contains supplementary material available at https://doi.org/ 10.1038/s41598-021-01338-8.

Correspondence and requests for materials should be addressed to L.G.

Reprints and permissions information is available at www.nature.com/reprints.

Publisher's note Springer Nature remains neutral with regard to jurisdictional claims in published maps and institutional affiliations.

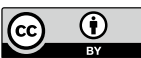

Open Access This article is licensed under a Creative Commons Attribution 4.0 International License, which permits use, sharing, adaptation, distribution and reproduction in any medium or format, as long as you give appropriate credit to the original author(s) and the source, provide a link to the Creative Commons licence, and indicate if changes were made. The images or other third party material in this article are included in the article's Creative Commons licence, unless indicated otherwise in a credit line to the material. If material is not included in the article's Creative Commons licence and your intended use is not permitted by statutory regulation or exceeds the permitted use, you will need to obtain permission directly from the copyright holder. To view a copy of this licence, visit http://creativecommons.org/licenses/by/4.0/.

(C) The Author(s) 2021 